\title{
An Evaluation of the Reproductive Performance of Sahiwal Heifers in the High Humid Climatic Condition of Assam
}

\author{
Upasana Baruah, Purabi Kaushik, D. Kalita, F. Akhtar, K.B. Kalita
}

10.18805/ajdfr.DR-1682

\begin{abstract}
Background: An evaluation of the reproduction performance of Sahiwal heifers was carried out outside of their original habitat due to the unavailability of performance record in the north-eastern part of India as this region being different from others because of possessing high humidity.

Methods: Eighteen numbers of Sahiwal heifers maintained at the Sahiwal Cattle Farm in College of Veterinary Science, Assam Agricultural University, Khanapara, Guwahati, Assam were utilized for a period from August 2017 to January 2020. The resultant mean for different reproduction traits were carried out with the help of simple analysis technique of mean.

Conclusion: The results for different reproduction traits were found to be in the normal range. This study confirmed that the Sahiwal breed can thrive well in the high humid climatic region of Assam.
\end{abstract}

Key words: Humid climatic region, Reproductive traits, Sahiwal cow.

\section{INTRODUCTION}

The demand for organic food is increasing day by day as today's world is more concerned about healthy and diseased free livelihood. There is always need to increase the quantity of products to fulfill the demand. Judgment on an animal cannot be passed by separating productive characteristics from their reproducing ability. In other terms, good reproductive parameters reflect the animal to be excellent in their production level. According to FAO (2020), the largest value-added countries in terms of agriculture, forestry, and fishing sector in 2018 are China, India, and the United States of America. Agricultural output is incomplete without mentioning the contribution provided by the livestock sector. The outcome of milk from the north-eastern part of India, mainly from Assam was 0.882 million tonnes during 2018-19. The per capita availability of milk in this region is quite less which is 71 grams per day.

Sahiwal is an outstanding milch breed of cattle originated at Montgomery district of Punjab, Pakistan. Sahiwal is known to produce a larger quantity of milk and contains high fat content in their milk as compared to other indigenous milch breeds. This breed can thrive easily in high humid areas. The special characteristic of having loose skin around their body makes them fairly resistant to tick-borne diseases (Reddy, 2019). Because of its desirable traits, it is being utilized widely in many warm humid countries of the world for improvement of local stock or crossbreeding of indigenous stock. According to Breed Survey, Department of Animal Husbandry, Dairying and Fisheries, Govt. of India, 2013, the pure breed Sahiwal cattle population in India was $10,92,459$. This purebred population has not received much attention despite having a profound impact on the rural economy and their significant contribution in terms of milk production. This purebred population is decreasing day by day due to the introduction of exotic animals and changes
College of Veterinary Science, Agricultural University, Jorhat-785 013, Assam, India.

Corresponding Author: Purabi Kaushik, Department of Animal Genetics and Breeding, College of Veterinary Science, Khanapara, Guwahati-781 022, Assam, India. Email: purabiicar@gmail.com

How to cite this article: Baruah, U., Kaushik, P., Kalita, D., Akhtar, F. and Kalita, K.B. (2021). An Evaluation of the Reproductive Performance of Sahiwal Heifers in the High Humid Climatic Condition of Assam. Asian Journal of Dairy and Food Research. DOI: 10.18805/ajdfr.DR-1682.

Submitted: 10-04-2021 Accepted: 02-07-2021 Online: 31-07-2021

in the agricultural system. Reduction of breed population can be minimized by making it commercially available under existing circumstances. There is also a need to enhance the adaptability of the Sahiwal breed in regions outside its breeding tract. To reduce the extinction of this pure breed from nature, adoption of conservation process is of utmost importance. Rearing at field level with scientific management system would help serve the conservation along with fulfilling the demand of consumers for their products. In Assam, their performance has not been evaluated so far as the availability of pure Sahiwal breed is very less in the north-eastern part of India. The present work would strengthen field workers and the rural poor by increasing their monthly income.

\section{MATERIALS AND METHODS Location of work}

The present study was carried out at the department of Animal Genetics and Breeding College of Veterinary Science, Assam Agricultural University, Khanapara, Guwahati-781022, Assam, India. 


\section{Feeding and management}

The particular herd was maintained with sufficient care and special concern was undertaken to avoid discomforts. The cattle sheds' constructed scientifically within the farm complex were used for housing the animals, having all the facilities for the comfort of animals. Scientific management and breeding practices were carried out. Proper cleaning and sanitization were followed regularly to maintain the hygiene inside the farm complex. Stall feeding and open grazing practices are followed. Feeding practices are done both at morning and evening times in the separate feeding troughs and ad libitum water is also supplied through water channels.

\section{Data source and data collection}

The pure breed of Sahiwal heifers was taken as the breed of study in our research programme. The data were collected from the Sahiwal Cattle Farm, College of Veterinary Science, Assam Agricultural University, Khanapara, Guwahati, Assam, India over a period of 2.5 years (from August 2017 to January 2020) by utilizing a total of eighteen numbers of heifers maintained at that farm. This study aimed to analyze the first reproduction parameters of Sahiwal heifers in the high humid climatic condition of North-Eastern India, particularly Assam. This study has been approved by the Institutional Animal Ethics Committee.

\section{Traits of study}

Reproduction traits such as age at maturity, age at first fertile service, age at first calving, first service period, first gestation length and first inter calving period were taken for study.

\section{Statistical analysis}

Simple analysis technique to determine averages of different reproduction traits along with their coefficient of variation was carried out.

\section{RESULTS AND Discussion Age at sexual maturity}

The average value and its standard error for age at sexual maturity are presented in Table 1 . In the present study, the overall mean for age at sexual maturity was found to be $892.89 \pm 43.20$ days and its coefficient of variation was $20.53 \%$. Higher than the present findings were reported by Malik and Ghei (1977) and Gaur et al. (2003) for Gir heifers being 1096 days and $1149 \pm 58$ days, respectively. The age at maturity of Sahiwal heifers was mainly controlled by environmental factors. Better management of dams in advanced pregnancy and calves in the early stage may result in early maturity as reported by Yadava et al. (2010). Novakovic et al. (2011) explained in their research that the time of sexual maturity depends on numerous genetic and environmental factors like nutrition, climate, rearing, and housing of cows. Scientific management practices might be the cause of lower age to become sexually mature in our herd of study.

\section{Age at first fertile service}

The average value and its standard error forage at first fertile service are presented in Table 1 . In the present study, the overall mean for age at first fertile service was found to be $1044.79 \pm 37.16$ days and its coefficient of variation was $13.31 \%$. There is very limited research that exists for determining the average age at which the animal performs first fertile service. Wu et al. (2012) and Novakovic et al. (2011) found relatively lower values for age at first fertile service as compared to our result. Higher value for age at first fertile service might result due to the lower availability of higher quality semen straw. Moreover, the herd was introduced newly in high humid area away from their original habitat. So they might take a longer period to overcome their stress level.

\section{Age at first calving}

The average value and its standard error for age at first calving are presented in Table 1. In the present study, the overall mean for age at first calving was found to be 1236.79 \pm 92.83 days and its coefficient of variation was $28.08 \%$. The average value for age at first calving in the present study is fairly comparable with the report of Chandrakala and Sinniah (2002) in Sahiwal cows (41 \pm 6.9 months). Lower than the present finding has been reported by Narwaria et al. (2015) and Wakchaure and Meena (2010) in Sahiwal cows being $1136.14 \pm 10.48$ days and $1078.09 \pm 21.12$ days, respectively. Kumar et al. (2017) studied in Jersey crossbred heifers and found $1089.36 \pm 13.99$ days of age at first calving with the coefficient of variation $14.27 \%$. A relatively higher value for age at first calving was reported by Rehman et al. (2008) in Sahiwal cows (1390 \pm 3.9 days) and Moulick etal. (1972) in Deshi cows (44.5 \pm 6.8 months). Lower age of first calving was reported by Sherwin et al. (2016), Jadhav et al. (2019) and Beneberu et al. (2021) for U.K. dairy herds (29.6 months), $\mathrm{HF} \times$ Gir half breed cows (990.69 \pm 6.53 days) and Jersey Cattle (32.95 \pm 0.22 months), respectively.

Table 1: Simple averages with standard errors for different reproductive traits.

\begin{tabular}{lccc}
\hline Traits & $\mathrm{N}$ & Mean \pm SE & CV\% \\
\hline Age at sexual maturity & 18 & $892.89 \pm 43.20$ & 20.53 \\
Age at first fertile service & 14 & $1044.79 \pm 37.16$ & 13.31 \\
Age at first calving & 14 & $1236.79 \pm 92.83$ & 28.08 \\
First service period & 14 & $153.21 \pm 21.60$ & 52.76 \\
First gestation length & 14 & $283.00 \pm 1.44$ & 1.90 \\
First inter-calving period & 12 & $532.42 \pm 51.24$ & 33.34 \\
\hline
\end{tabular}

$\mathrm{N}$ : Number of observations; SE: Standard error; CV: Coefficient of variation. 


\section{First service period}

The average value and its standard error for the first service period are presented in Table 1. In the present study, the overall mean for the first service period was found to be $153.21 \pm 21.60$ days and its coefficient of variation was $52.76 \%$. Relatively similar to our research result were reported by Ahmad (1999) and Naskar et al. (2005) for Sahiwal cows being 153 days and $137.67 \pm 7.87$ days, respectively. In another study, Deshpande et al. (1983) reported $154 \pm 5.3$ days for Friesian $X$ Sahiwal crossbred cow. Lower than the present finding was reported by Jadhav et al. (2019) for HF $\times$ Gir half bred cow. Relatively higher values were reported by Narwaria et al. (2015); Rehman et al. (2008); Talbott (1997) for Sahiwal cows and by Wu et al. (2012) for Chinese Holstein cows. Much higher service period was averaged out by Dandapat et al. (2010) for Sahiwal and crossbred cows (284.50 \pm 1.29 and $263.17 \pm 6.67$ days); Malik and Ghei (1977) for Gir heifers (317 days). The increased value for service period found in our result could be controlled by minimizing the environmental variation and by providing a proper postpartum cow management system.

\section{First gestation length}

The average value and its standard error for the first gestation length are presented in Table 1 . In the present study, the overall mean for the first service period was found to be $283.00 \pm 1.44$ days and its coefficient of variation was $1.90 \%$. Relatively similar to our research results were reported by Malik and Ghei (1977) for Gir heifers (287 days); Chandrakala and Sinniah (2002) for Sahiwal cows (279 \pm 6 days); Naskar et al. (2005) for Sahiwal cows (286.67 \pm 0.46 days). For Jersey $X$ Local cows, Holstein Friesian $X$ Local and Local cows, the gestation length was $275.74 \pm 0.46$ days, $275.81 \pm 0.53$ days and $274.12 \pm 0.53$ days, respectively as reported by Hussain et al. (2012). Das et al. (1990) and Hussain et al. (2012) explained in their research that the gestation length is affected by different factors like season of calving, lactation order, genetic group and sex of the calf.

\section{First inter-calving period}

The average value and its standard error for the first inter calving period is presented in Table 1 . In the present study, the overall mean for the first inter calving period was found to be $532.42 \pm 51.24$ days and its coefficient of variation was $33.34 \%$. Relatively similar values were reported by Dandapat et al. (2010) for Sahiwal (522.63 \pm 27.99 days) and crossbred cattle (500.13 \pm 35.35 days). Lower than our research findings were reported by Chandrakala and Sinniah (2002); Zafar et al. (2008) and Narwaria et al. (2015) for Sahiwal cows. Higher than the present findings was obtained by Malik and Ghei (1977) for Gir heifers (603 days). For Holstein Friesian cows and HF $\times$ Gir half breed cows; lower inter calving period were reported by Froidmont et al. (2013) and Jadhav et al. (2019), respectively. Higher values found for first inter calving period could be controlled by minimizing the environmental variation and by providing a proper postpartum cow management system.

\section{CONCLUSION}

Utilization of pure breed Sahiwal cattle outside of their breeding tract proved that this breed can able to thrive and perform very well in terms of their reproduction performances. This particular herd would be helpful to serve the poor and landless farmers in the entire region of Assam. Selection followed by up-gradation of local cattle with Sahiwal lightens up another area of improvement for the entire breeders association. Providing adequate nutrition, care, exercise, and a housing system leads to more economic returns with limited uses of inputs. It would ultimately help the Government to widen their area of economic uptake on a large scale.

\section{ACKNOWLEDGEMENT}

The author is grateful to the facilities available in the Sahiwal Cattle Farm, College of Veterinary Science, Assam Agricultural University, Khanapara. The author will be ever grateful to Dr. R. N. Goswami, for providing a helping hand to analyze data successfully. Lastly, the author wishes to thank all the authors for their valuable suggestions.

\section{REFERENCES}

Ahmad, M. (1999). Genetic Evaluation of Native and Crossbred Dairy Cattle in Pakistan. Ph. D. Thesis, Dept. Anim. Genet. Breed. Univ. New England, Australia.

Beneberu, N., Alemayehu, K., Mebratie, W., Getahun, K. and Tesema, Z. (2021). Evaluation of Reproductive Performance of Jersey Cattle Raised under Semi-intensive Management in Ethiopia. Asian Journal of Dairy and Food Research. 40 (1): 8-13.

Chandrakala, V. and Sinniah, J. (2002). Performance of Sahiwal cattle at Nikawaretiya farm, Srilanka. Tropical Agriculturists. 154: 43-50.

Dandapat, A., Banerjee, D. and Chakraborty, D. (2010). Genetic studies on various production and reproduction traits of Sahiwal and crossbred cattle (HF $\times$ Jersey $\times$ Sahiwal) of an organised farm. Veterinary World. 3 (4): 167-168.

Das, G.C., Das, D. and Aziz, A. (1990). Production and reproductive performance of Jersey cows in Assam. Livestock Adviser. 15 (3): 3-7.

Deshpande, K.S., Ingole, G.K. and Sakhare, P.G. (1983). Factors affecting service period and calving interval in Friesian $X$ Sahiwal crossbreds. Indian Journal of Animal Science. 58: 986-987.

FAO (2020). World Food and Agriculture - Statistical Yearbook 2020. Rome.

Froidmont, E., Mayeres, P., Picron, P., Turlot, A., Planchon, V. and Stilmant, D. (2013). Association between age at first calving, year and season of first calving and milk production in Holstein cows. Animal. 7 (4): 665-672.

Gaur, G.K., Kaushik, S.N. and Garg, R.C. (2003). The Gir cattle breed of India - characteristics and present status. Animal Genetic Resources Information. 33: 21-29. 
Hussain, J., Roychoudhury, R., Das, G.C., Mili, D.C. and Goswami, R.N. (2012). Reproductive performance of dairy cows under field condition of Assam state. Indian Journal of Animal Research. 46 (2):180-183.

Jadhav, S.S., Deokar, D.K., Fulpagare, Y.G., Bhoite, U.Y., Mandkmale, S.D. and Nimbalker, C.V. (2019). Effect of Genetic and Non-Genetic Factors on First Lactation Production and Reproduction Traits in HF $\times$ Gir Cattle. International Journal of Current Microbiology and Applied Sciences. 8 (1): 45-51.

Kumar, A., Mandal, A., Gupta, A.K., Ratwan, P. and Kumar, N. (2017). Genetic evaluation of reproductive traits in Jersey crossbred heifers at an organized farm of eastern India. Indian Journal of Animal Research. 51 (4): 619-624.

Malik, B.S. and Ghei, G.C. (1977). A note on some production characteristics of Gir cattle. Indian Journal of Animal Sciences. 47: 587-588.

Moulick, S.K., McDowell, R.E., Van Vleck, L.D. and Guha, H. (1972). Potential of Deshi Cattle of India for Dairy Production. Journal of Dairy Science. 55 (8): 1148-1155.

Narwaria, U.S., Mehla, R.K., Verma, K.K., Prasad, S., Gupta, A.K., Lathwal, S.S. and Verma, A.K. (2015). Non-genetic factors affecting economic traits in Sahiwal cattle at organized farm. Indian Journal of Dairy Science. 68 (4): 379-383.

Naskar, S., Banik, S. and Tomar, S.S. (2005). Total determination of calving interval by path analysis in Sahiwal cattle. Indian Journal of Animal Research. 39 (1): 45-48.

Novakovic, Z., Sretenovic, L., Aleksic, S., Petrovic, M.M., Pantelic, V. and Ostojic-Andric, D. (2011). Age at first conception of high yielding cows. Biotechnology in Animal Husbandry. 27 (3): 1043-1050.
Reddy, S. (2019). Sahiwal Cow Characteristics. Natural Farming Report.

Rehman, Z.U., Khan, M.S., Bhatti, S.A., Iqbal, J. and lqbal, A. (2008). Factors affecting first lactation performance of Sahiwal cattle in Pakistan. Archives Animal Breeding. 51 (4): 305-317.

Sherwin, V.E., Hudson, C.D., Henderson, A. and Green, M.J. (2016). The association between age at first calving and survival of first lactation heifers within dairy herds. Animal. 10 (11): 1877-1882.

Talbott, C.W., Chauhdry, M.Z., McDowell, R.E. and McDaniel, B.T. (1997). Potential to increase milk yield in tropical countries with indigenous dairy cattle. The Sahiwal Model. Journal of Animal and Plant Sciences (Pakistan). 7 (1-2): 1-10.

Wakchaure, R.S. and Meena, R. (2010). Factors affecting, birth weight, age and weight at first calving in Sahiwal cattle. Indian Journal of Animal Research. 44 (3): 173-177.

Wu, J.J., Wathes, D.C., Brickell, J.S., Yang, L.G., Cheng, Z., Zhao, H.Q., Xu, Y.J. and Zhang, S.J. (2012). Reproductive performance and survival of Chinese Holstein dairy cows in central China. Animal Production Science. 52 (1): 11-19.

Yadava, R., Lathwal, S.S., Singh, Y., Dangi, R.L. and Roy, B.K. (2010). Effect of genetic and non-genetic factors on body weight of Sahiwal cows. The Indian Veterinary Journal. 87 (12): 1217-1220.

Zafar, A.H., Ahmad, M. and Rehman, S.U. (2008). Study of some performance traits in Sahiwal cows during different periods. Pakistan Veterinary Journal. 28 (2): 84-88. 